\title{
TREN IJTIHAD KONTEMPORER
}

\author{
Supari
}

\section{Abstract}

Problemsrelated to Islamiclawcome inaccordance withsocial changing. The problems sometimes are only in different forms. Yusuf Qandhawi's theory about ïtihad related mud in classifying those problems. For those problems that have ever been discussed, they need to be reanalyzed using taniqab al tarjib to obtain the strongest ar gumentation. Meamwilefor thenew problems, they might be discussed by ijtihad inshāit.

Kata Kunci: Perubahan Masyarakat, Ijtihad Tarj̣̄̄n, Ijtihad Inshä i

\section{A. Pendahuluan}

Masyarakat senantiasa mengalami perubahan. Perubahan masyarakat itu dapat berupa perubahan tatanan sosial, budaya, sosialekonomi dan lain-lainnya. Menurut para ahli linguistik dan semantik, bahasa akan mengalami perubahan setiap sembilan puluh tahun. Perubahan dalam bahasa, secara langsung atau tidak langsung mengandung arti perubahan dalam masyarakat itu. ${ }^{1}$ Pernyataan tersebut menarik untuk diperhatikan, sebab Nabi Muhammad saw. pernah mengatakan, bahwa setiap seratus tahun (seabad) akan ada orang yang

Penulis adalah dosen tetap Jurusan Syariah STAIN Purwokerto, alumnus Program Pascasarjana (S2) UIN Syarif Hidayatullah Jakarta.

'Lihat Harun Nasution, "Dasar Pemikiran Pembaharuan dalam Islam”, dalam M. Yunan Yusuf, et al (ed), Cita dan Citra Muchammadiycob (Jakarta: Pustaka Panjimas, 1985), hal. 19. 
bertugas memperbaharui pemahaman keagamaan. ${ }^{2}$ Agaknya, pernyataan $\mathrm{Nabi}$ itu sejalan dengan hasil penelitian para ahli linguistik dan semantik itu.

Berdasarkan teori di atas, maka berarti sejak Nabi Muhammad saw. wafat, umat Islam telah mengalami perubahan sebanyak lima belas kali. ${ }^{3}$ Pada setiap abad mestinya terdapat seorang mujaddid atau seorang mujtahid pada zamannya. Hal ini berarti bahwa ijtihad para ulama terdahulu mestinya sesuai dengan waktu dan keadaan di mana mereka berada, namun belum tentu sesuai dengan keadaan umat Islam sekarang. Karena itu sangat bijaksana Ibn Qayyim yang menyatakan: ${ }^{4}$

$$
\text { تغير الفتوى بتغير الأزمان والأكنة والأحوال والعوائد }
$$

Maksud ungkapan di atas adalah bahwa kondisi suatu masyarakat akan berpengaruh terhadap fatwa yang dikeluarkan oleh seorang mufti. Namun hal ini tidak berarti bahwa hukum akan berubah begitu saja, tanpa memperhatikan norma yang terdapat dalam sumber utama hukum Islam, al-Qur'an dan hadis. ${ }^{5}$

Sejarah mencatat, bahwa ijtihad telah dilaksanakan dari masa ke masa, sejak masa awal Islam sampai sekarang. Kalau pada masa lampau mujtahid didambakan keberadaannya oleh umat Islam, maka sekarang keberadaannya sangat diharapkan. Tentunya mujtahid sekarang harus dapat menyelesaikan masalah-masalah kontemporer, terutama setelah adanya perubahan masyarakat, sebagai akibat kemajuan ilmu pengetahuan dan teknologi. Karena itu ijtihad masa sekarang jauh lebih diperlukan dibandingkan dengan masa-masa lampau.

${ }^{2}$ Adapun hadis yang dimaksud sebagai berikut:

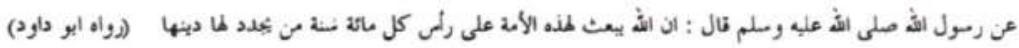
Lihat Abu Dawud, Sunan Abi Danud (Ttp.: Där al-Fikr, t.t.), IV: 109.

'Nasution, "Dasar Pemikiran."

"Ibn al-Qayyim, Itam al-Munagqtin 'an Rabb al-Ālamin (Beirut: Där al-Fikr, t.t.), III: 14.

${ }^{3}$ Fathurrahman Djamil, Filsafat Hukum Islam (Jakarta: Logos, 1999), hal. 164. 


\section{B. Urgensi Ijtihad dalam Perkembangan Fikih (Hukum Islam)}

Fikih $^{6}$ sebagai interpretasi dari syari'ah (nas-nas al-Qur'an dan sunnah) memiliki watak "dinamis". Hal ini sesuai dengan ungkapan para pakar hukum Islam bahwa hukum Islam itu șälị li kulli zamān wea makān (sesuai untuk dipedomani dalam segala waktu dan tempat). Dengan wataknya yang dinamis itu, fikih memiliki dinamika yang sangat tinggi dan mampu mengakomodir segala persoalan baru yang ditimbulkan oleh perkembangan sosial. Ke-dinamis-an fikih (hukum Islam) itu telah diisyaratkan oleh wahyu al-Qur'an yang terakhir, bahwa agama Islam telah dinyatakan sempurna di akhir hayat Rasulullah saw sebagai rasul yang terakhir?

Fenomena fikih boleh dikatakan sangatkontras dengan fenomena ilmu pengetahuan dan teknologi yang terus mengalami sofistikasi. Penemuan-penemuan baru di bidang teknologi yang terus melaju dengan cepat, hendaknya diimbangi dengan fikih yang canggih pula. Kenyataannya sekarang fikih bergerak sangat lamban bahkan terkesan mandeg. Fikih lama masih dipegangi secara kokoh, sementara itu fikih baru belum juga lahir, misalnya fikih yang berbicara tentang dunia internet, sistem perbankan dan lain-lain.

${ }^{6}$ Fikih atau hukum Islam 'amali merupakan sistem hukum di dalam Islam yang bertujuan merealisasikan dan melindungi kemaslahatan umat manusia. Fikih bukanlah hukum murni dalam pengertiannya yang sempit, ia mencakup seluruh bidang kehidupan, etika, keagamaan, politik dan ekonomi. Hukum Islam diformulasikan sebagai sekumpulan aturan keagamaan yang mengatur perilaku kehidupan kaum muslim dalam segala aspeknya baik yang bersifat individual maupun kolektif. Karakteristiknya yang serba mencakup inilah, yang menempatkannya pada posisi penting dalam pandangan umat Islam. Bahkan sejak awalnya, hukum Islam telah dianggap sebagai pengetahuan par exellence - suatu posisi yang belum pernah dicapai teologi. Itulah sebabnya para pengamat Barat menilai : "Adalah mustahil memahami Islam tanpa memahami hukum Islam." Lihat, Joseph Schacht, An Introduction to Islamic Law (London: Oxford University Press, 1971), hal. 1; Taufik Adnan Amal, Islam dan Tantangan Modernitas: Studi atas Pemikiran Hukum Fazlur Rdmm (Bandung: Mizan, 1994), hal. 33.

'Satria Efendi, "Ijtihad Sepanjang Sejarah Hukum Islam: Memposisikan K.H. Ali Yafie," dalam Jamal D. Rahman (ed.), Wacana Baru Fikih Sosial 70 Tabun K.H. Ali Yafie (Bandung: Mizan, 1997), hal. 146 
Perkembangan dan perubahan sosial menimbulkan berbagai corak baru dalam kehidupan manusia, sementara nas sudah tidak bertambah lagi. Di kalangan ahli hukum Islam sering dijumpai ungkapan: al-nușūs al-mutanāhiyah wa al-waqā'i' ghayr mutanāhiyah ${ }^{8}$ (nasnas itu terhenti, sedangkan peristiwa yang terjadi tidak terhenti). Dari kenyataan di atas diperlukan upaya sungguh-sungguh untuk menjawab setiap persoalan yang muncul. Inilah yang sering disebut sebagai "ijtihad".

Kewajiban umat Islam (terutama hakim - selaku penegak hukum - dan ulama serta mufti) untuk berijtihad, menggali, mengikuti dan memahami nilai-nilai hukum yang hidup dalam masyarakat, baik dalam konsep fikih Islam maupun perundang-undangan tidaklah perlu diperdebatkan.

Legalitas tersebut dapat ditangkap dari sikap Rasulullah dalam memuji Mu'adz bin Jabal ketika akan memutuskan perkara dengan ijtihad, manakala tidak ditemui hukumnya dalam al-Kitab dan Sunnah. $\mathrm{Hal}$ demikian termaktub dalam hadis yang diriwayatkan Mu'adz bin Jabal sewaktu beliau diutus ke Yaman: ${ }^{9}$

$$
\begin{aligned}
& \text { أن رسول الله صلى الله عليه وسلم بعث معاذا الى اليمن فقال : كيف تقضى ؟ } \\
& \text { فقال : أقضى بما في كتاب الله قال : فان لم يكن في كتاب الله ؟ قال : فبسنة } \\
& \text { رسول الله. قال : فان لم يكن في سنة رسول الله صلى الله عليه وسلم ؟ قال : } \\
& \text { أجتهد رأيى. قال : الحمد لله الذى وفق رسول رسول الله }
\end{aligned}
$$

${ }^{8}$ Al-Suyūūi, Taysìr al-Ijtihăd (Makkah al-Mukarramah: Maktabah al-Tijāriyah, 1982), hal. 22. Redaksi lain seperti yang disampaikan oleh Ibn Rushd dalam kitab Bidayah al-Mujiahid wa Nibäyah al-Muqtașid (Semarang: Thoha Putra, t.t), I: 2, adalah "anna al-wagā ' $i$ ' bayna asblehās al-wnäi ghogru mutanäbijab wa al-nușus wa al-af'al wa al-igrärät mutanähijab."

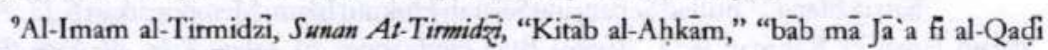
Kayfa Yaqđ̣i, (Beirūt : Dār al-Fikr), II: 394. 
Begitu besarnya nilai legalitas ini, sehingga sekalipun hasil ijtihad itu salah (keliru) masih tetap memperoleh satu pahala, dan dua pahala jika hasil ijtihadnya benar. Sabda Rasulullah: ${ }^{10}$

$$
\begin{aligned}
& \text { عن عمرو بن العاص انه سمع رسول الله صلى الله عليه وسلم قال : اذا حكم } \\
& \text { الحاكم فاجتهد ثم اصاب فله اجران واذا حكم فاجتهد ثم أخطأ فله أجر . }
\end{aligned}
$$

Hal penting yang menjadi catatan sejarah dalam kaitannya dengan kemampuan hukum Islam dalam menghadapi perkembangan sosial itu adalah : pertama, keluwesan sumber bukum Islam, artinya al-Qur'an disamping mengandung hukum-hukum yang rinci dan menurut sifatnya tidak berkembang, juga mengandung hukum yang masih memerlukan penafsiran dan mempunyai potensi untuk berkembang. Kedua, semangat ijtibad berdasarkan keablian. Mengingat kerja ijtihad memerlukan kesungguhan dan keahlian tentang al-Qur'an, Sunnah Rasulullah dan ilmu-ilmu yang berhubungan dengan itu, maka yang melakukan ijtihad hanyalah mereka yang mempunyai keahlian untuk itu. Ketiga, berijtihad dengan metodologi usul fikih, dalam usaha menggali makna al-Qur'an dan sunnah Rasulullah. Dengan usul fikih, kajian al-Qur'an dan Sunah dapat dikembangkan dari segi substansi disamping dapat dikembangkan dari segi kebahasaannya. Tak heran kalau pengembangan hukum Islam melalui kajian al-Qur'an dari segi subtansinya lebih banyak menampung masalah-masalah baru.

Para imam mujtahid masa silam, berpegang teguh pada prinsip "seseorang yang berijtihad harus mengetahui batas kewenangan ijtihad dalam wahyu Allah," agar mengetahui mana yang menjadi lapangan ijtihad, dan mana yang tidak. Hasil ijtihad yang menyimpang dari prinsip tersebut khususnya dan kaidah-kaidah usul fikih umumnya, biasanya tidak akan bertahan lama. Maka, dari sekian banyak mazhab yang

${ }^{10}$ Muslim, Șậth Muslim (Bandung: Shirkah al-Ma'ärif li al-Ṭab' wa al-Nashr, t.t.), II: 
muncul dalam sejarah hukum Islam, mazhab yang bertahan lama dan dianut oleh umat Islam sampai sekarang di kalangan sunni adalah empat mazhab, yaitu Hanafi, Maliki, Syafi'i dan Hanbali. Dengan berpegang kepada metodologi ijtihad itu pula secara bertanggung jawab masingmasing mujtahid berani mengatakan bahwa hasil ijtihadnya adalah hukum Allah atau Rasul-Nya. ${ }^{11}$

Sebagai produk ijtihad, maka sudah sewajarnya jika fikih terus berkembang lantaran pertimbangan-pertimbangan sosio-politik dan sosio-budaya serta pola pikir yang melatarbelakangi hasil penggalian hukum sangat mungkin mengalami perubahan. Para peletak dasar fikih, yakni para imam mazhab (migtabidim) dalam melakukan formulasi hukum Islam meskipun digali langsung dari teks asal (al-Qur'an dan Sunnah) namun selalu tidak lepas dari pertimbangan "konteks lingkungan" keduanya baik asbäb al-nuzül maupun asbäb al-rerrüd.

Karena sadar bahwa fikih merupakan produk ijtihad, maka para fuqaha terdahulu baik al-aimmah al-arba'ah maupun yang lain meskipun berbeda pandangan secara tajam, mereka tetap menghormati pendapat lain, tidak memutlakkan pendapatnya dan menganggap ijtihad fuqaha lain sebagai keliru. Mereka tetap berpegang pada kaidah "al-z̈tibä la yumqadu bi-al-ijtihäd", yakni bahwa suatu ijtihad tidak bisa dibatalkan oleh ijtihad lain. Masing-masing memiliki kelebihan dan kekurangan. Di sinilah fikih menunjukkan wataknya yang fleksibel, dinamis, realistis dan temporal, tidak kaku dan tidak permanen.

Ditegaskan bahwa muara fikih adalah terciptanya keadilan sosial di masyarakat. Dengan kerangka berfikir demikian, maka jika ada produk fikih yang tidak bermuara pada terciptanya sebuah keadilan di masyarakat, maka harus ditinggalkan dan harus dibuat fikih baru. Harus diingat bahwayang namanya fikih itu mesti ijtihadi. Fikih siyasah, misalnya, itu sendiri bukan sebatas kekuasaan tetapi lebih pada kebijakan-kebijakan yang dapat menimbulkan kemaslahatan umum.

"Efendi, "Tjitihad," hal. 147-150. 
Rumusan itu harus mengacu pada prinsip magāșid al-shäri'ab yang meliputi lima hal, yaitu (1) melindungi agama (bifzal-din), (2) melindungi jiwa dan keselamatan fisik (bifzal-nafs), (3) melindungi kelangsungan keturunan (bifz al-nas), (4) melindungi akal pikiran (bifz al-aqh), dan (5) melindungi harta benda (bifz al-mál). Termasuk dalam kelima kebutuhan primer (darūiñ ) tersebut menurut sebagian ulama adalah "harga diri" (bifz al-irạ) yang disuruh Allah untuk menjaganya dan melarang berbuat sesuatu yang dapat mencemarkannya. ${ }^{12}$ Dalam hal ini diharamkan menuduh perempuan baik-baik melakukan zina tanpa bukti yang sah dan pelakunya diancam dengan 80 kali cambuk, sebagaimana firman Allah dalam surat al-Nur [24] ayat 4.

Rumusan lima maqäsid ini memberikan pemahaman bahwa Islam tidak mengkhususkan perannya hanya dalam aspek penyembahan Tuhan dalam arti yang terbatas pada serangkaian perintah dan larangan yang tidak dapat secara langsung dipahami manfaatnya. Dalam kerangka pemikiran ini, maka aspek kehidupan apapun yang melingkupi kehidupan manusia (kecuali yang bersifat ubudiyah murni) harus disikapi dengan meletakkan kemaslahatan ${ }^{13}$ sebagai bahan pertimbangan. Karena dengan hanya menjaga stabilitas kemaslahatan inilah tugas-tugas peribadatan dapat dilaksanakan dengan baik.

Jadi, sejak awalnya syari'at Islam sebenarnya tidak memiliki basis lain kecuali kemaslahatan manusia. Ungkapan standar, bahwa syari'at Islam dicanangkan demi kebahagiaan manusia, lahir batin, duniaakhirat, sepenuhnya mencerminkan kemaslahatan tadi. Akan tetapi, keterikatan yang berlebihan terhadap teks (nas), seperti dipromosikan

${ }^{12}$ Amir Syarifuddin, Usbul Fikib (Jakarta: Logos Wacana Ilmu, 1999), II: 212.

${ }^{13}$ Menurut penelitian para ulama, sebagaimana dikutip oleh Ibrahim Hosen, bahwa kemaslahatan dapat diklasifikasikan menjadi tiga aspek, yakni: darürijāt (primer), häjijyät (sekunder) dan tahisinjyät (pelengkap). Terdorong maksud ingin memberikan kemaslahatan itulah, ada bagian fikih yang dinamakan siyasab shar'ijyab, yakni kebijaksanaan untuk membuat masyarakat lebih dekat kepada kebajikan dan menjauhi keburukan. Lihat Ibrahim Hosen, "Jenis-Jenis Hukuman dalam Hukum Pidana Islam (Reinterpretasi Terhadap Pelaksanaan Aturan)" dalam Rahman, Wacana Baru, hal. 33. Menurut Hasbi Ash Shiddiqi, siyäsab shar'jyaab pada dasarnya sama dengan mașlạ̧ab mursalab itu sendiri. 
oleh paham ortodoksi, telah membuat prinsip kemaslahatan sebagai jargon kosong. ${ }^{14}$

Kaum ortodoks, yang berpegang pada al-Qur'an dan Sunnah secara tekstual, menganggap fikih sebagai sesuatu yang suci, sakral, final dan abadi. Mereka lebih banyak bergelut dengan realitas fikih yang sudah jadi. Sementara kaum modernis, menyikapi teks-teks keagamaan secara kontekstual dan menganggap fikih sebagai pemaknaan sosial atau rekayasa sosial sesuai dengan prinsip law as a tool of social engineering. ${ }^{15}$

Fikih sebenarnya upaya manusiawi, yang melibatkan proses penalaran (reasoning), baik dalam tataran teoritis maupun praktis, dalam memahami, menjabarkan dan mengelaborasikan hukum-hukum agama. Dengan menyebut manusiawi, dimaksudkan untuk membedakan dengan syari'at, yang secara longgar dipakai untuk menyebut agama Islam dan merujuk kepada hukum Tuhan sebagaimana terkandung dalam korpus-korpus wahyu, tanpa melibatkan unsur-unsur manusia. Pendeknya fikih adalah refleksi dari syari'at. ${ }^{16}$

\section{Ijtihad Sebagai Salah Satu Sumber dan Metode Penetapan Hukum}

Kata "sumber" dalam hukum fikih adalah terjemahan dari lafaz mașdar, jamaknya: mașädir. Kata ini hanya terdapat dalam sebagian literatur kontemporer sebagai ganti dari sebutan dalil atau lengkapnya "al-adillah al-shar" "yyah" dalam literatur klasik. Ada juga kata adillab alahkām(dalil-dalil hukum) sama pengertiannya dengan kata ușül al-aḥkām (dasar-dasar hukum) dan mașädir alaḅkàm (sumber-sumber hukum). ${ }^{17}$

${ }^{14}$ Sumanto al-Qurthubi, K.H. Sahal Mabfudz: Era Baru Fikih Indonesia (Yogyakarta: Cermin, 1999), hal. 2.

${ }^{15}$ Ahmad Baso, "Melawan Tekanan Agama: Wacana Baru Pemikiran Fikih NU," dalam Rahman, Wacama Baru, hal. 132

${ }^{16}$ Sahal Mahfudz, Nuansa Fikib Sosial (Yogyakarta: LKiS, 1994), hal. 18.

${ }^{17}$ Mukhtar Yahya dan Fatchurrahman, Dasar-Dasar Pembinaan Hukum Fikih Islami (Bandung : Al-Ma'arif, 1993), hal. 27. 
Mereka yang menggunakan kata mașädir sebagai ganti al-adillah dan usūul al-aḅkām tentu beranggapan bahwa ketiga kata itu sama artinya.

Kata sumber diartikan suatu wadah, dari wadah itu dapat ditemukan atau ditimba norma hukum, sedangkan dalil hukum berarti sesuatu yang memberi petunjuk dan menuntun kita dalam menemukan hukum Allah. ${ }^{18}$

Di kalangan fukaha, kata dalil diartikan "sesuatu yang padanya terdapat penunjukan pengajaran, baik yang dapat menyampaikan kepada sesuatu yang meyakinkan atau kepada dugaan kuat yang tidak meyakinkan". Di kalangan ulama usul fikih kata dalil diartikan "sesuatu yang dipergunakan sebagai petunjuk pandangan yang sehat untuk menetapkan hukum syara' tentang amal perbuatan manusia secara qat'i (pasti) atau zami (dugaan keras)". ${ }^{19}$

Sumber hukum dapat dikelompokkan menjadi dua, yakni sumber hukum yang disepakati para ulama, al-Qur'an, Sunnah, ijmak dan qiyas; sumber hukum yang tidak disepakati, berupa istihsān, mașlaḅah mursalah, istiṣhạabs shar' man qablanā dan mazhab sahabat. Menurut Fathurrahman Djamil, kata sumber hanya berlaku pada al-Qur'an dan Sunnah, karena hanya dari keduanyalah digali norma-norma hukum. Sedangkan ijmak, qiyas, istiḥsān, istișḥab, istiștạ̣, dan istidlal tidak termasuk kategori sumber hukum. Kesemuanya itu termasuk dalil hukum. Dengan menggunakan istilah-istilah tersebut kita dapat menemukan hukumhukum Islam. Istilah-istilah tersebut merupakan alat dalam menggali hukum-hukum dari al-Qur'an dan Sunnah. ${ }^{20}$

Secara garis besar hukum dalam al-Qur'an dapat dikelompokkan menjadi tiga, yaitu :

1). Hukum itiqädyyah (aqidah). Hukum ini mengatur hubungan rohaniah manusia dengan Yang Maha Kuasa dalam masalah keimanan

${ }^{18}$ Syarifuddin, Ushul Fikih, I: 43; Khallaf, Kaidab-Kaidah, hal.17-18.

${ }^{19}$ Yahya dan Fatchurrahman, Dasar-Dasar. hal. 27.

${ }^{20}$ Djamil, Filsafat Hukum Islam, hal. 82. 
dan ketakwaan. Hukum yang berkaitan dengan kewajiban mukallaf untuk mempercayai Allah, malaikat, rasul, kitab-Nya dan hari pembalasan.

2). Hukum kbuluqiyyah (akhlak). Hukum ini mengatur hubungan manusia dengan manusia dan makhluk lain dalam hubungan beragama, bermasyarakat dan bernegara. Tercakup dalam hukum ini adalah tingkah laku yang berhubungan dengan kewajiban mukallaf untuk menghiasi dirinya dengan sifat-sifat keutamaan dan menjauhkan dirinya dari sifat-sifat tercela.

3). Hukum 'amaliyyab shar'iyyah (syari'ah). Hukum ini mengatur hubungan hidup lahiriyah antara manusia dengan makhluk lain, dengan Tuhannya selain yang bersifat rohani, dan dengan alam sekitarnya. Mukhtar Yahya dan Fatchurrahman menyebutnya sebagai figh al-Qur'ann. ${ }^{21}$ Itulah yang hendak dicapai oleh ilmu ushul fikih. Atau menurut M. Amin Suma menyebutnya dengan istilah figh al-kitäb (fikih al-Qur'an), ayat al-fiqhiyyah (ayat-ayat tentang fikih), atau abkām al-Qur'an, yang maksudnya kurang lebih sama saja yaitu merujuk kepada ayat-ayat al-Qur'an yang berisikan masalah hukum..$^{22}$ Sedangkan Hukum 'amaliyah dalam al-Qur'an itu terdiri atas dua macam yaitu hukum ibadat dan hukum mu'amalat.

Al-Qur'an ditinjau dari segi reroùd dan thubūt-nya adalah qat'i. Quți al- wrrüd al-Qur'an maksudnya bahwa lafaz dan makna al-Qur'an itu pasti datang dari Allah, sedang qat? $i$ al-thubut al-Qur'an dipahami bahwa al-Qur'an adalah wahyu Allah yang disampaikan kepada Nabi Muhammad saw, yang eksistensinya tidak diragukan lagi oleh setiap muslim.

${ }^{21}$ Yahya dan Fatchurrahman, Dasar-Dasar, hal. 35. Lihat juga Djamil, Filsafat Hukum ISlam, hal. 91.

${ }^{22}$ Muhammad Amin Suma, Pengantar Tafsir Abkam (Jakarta: Raja Grafindo Persada, 2001), hal. 26. 
Sedangkan Sunnah ${ }^{23}$ selain yang bersifat mutaweation ${ }^{24}$ ada juga yang bersifat zamū al-wurrü. Dari kenyataan inilah jumhur ulama menyatakan bahwa al-sunnah menempati urutan yang kedua dalam sumber hukum Islam. Sebagaimana dikutip oleh Fathurrahman Djamil dari pendapat al-Shạthibì dan al-Qāsimi, bahwa mereka (jumhur) memberikan alasan secara rasional dan tekstual. ${ }^{25}$

Di antara argumen itu adalah bahwa (1) al-Qur'an bersifat qat ${ }^{5}$ alrevrüd, sedangkan al-sunnah bersifat zampi al-reuruid. Karena itu yang $q a t^{T} i$ harus didahulukan dari yang zami ; (2) al-sunnah berfungsi sebagai penjelas dari al-Qur'an. Hal ini harus diartikan bahwayang menjelaskan berkedudukan lebih rendah dari yang dijelaskan. ${ }^{26} \mathrm{Jika}$ tidak ada mubayjan (yang dijelaskan), maka tidak perlu ada bayān (penjelasan), sebaliknya jika tidak ada bayān, maka mubayjan tidak mesti hilang dengan sendirinya; (3) terdapat beberapa hadis yang menjelaskan urutan (tertib jenjang) dan kedudukan al-sunnah setelah al-Qur'an.

${ }^{23}$ Secara etimologis, somah berarti jalan yang lurus dan berkesinambungan, yang baik

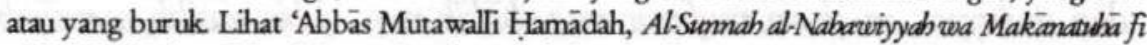
al-Tasbrì' (Kairo: Där al-Qawmiyyah, t.t.), hal.13. Lihat juga Muhammad Abū Zahrah, al. Haxîth wa al-Muhaddithün (Beirut: Där al-Kitāb al-'Arabi, 1993), hal. 8. Menurut istilah ahli Hadis, alsmmah adalah setiap apa yang diterima dari Rasul saw berupa perkataan, perbuatan, taqrir, sifat fisik atau akhlak, atau perikehidupan, baik sebelum beliau diangkat sebagai Rasul, seperti talhannuth di Gua Hurā' atau sesudah kerasulan beliau. Lihat 'Ajjäj al-Khațīb, Al-Sumnah qabla al-Tadwìn (Beirut: Dār al-Fikr, 1993), hal. 14. Pengertian ini tentu berbeda dengan pengertian sunnah menurut ulama ushul fikih dan ulama fikih.

${ }^{24}$ Sunnah mewwatimab adalah sunnah yang diriwayatkan oleh rawi yang jumlahnya banyak sehingga mustahil mereka bersepakat untuk berdusta. Periwayatan terjadi secara muavatir dengan jumlah rawi yang banyak yang meliputi tiga generasi, yaitu generasi sahabat, tabi'in dan

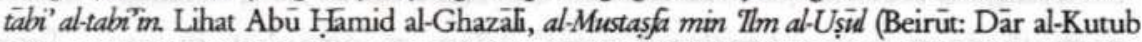
al-Inniyyah, 1983), I: 86. Lihat juga Muhammad ibn 'Ali ibn Muhammad al-Shawkāni, Irshàd al-Fuhül (Beirut: Dār al-Fikr, t.t.), hal. 14; Mușafă Sa'id al-Khin, Athar al-Ikhtitaffi al-Qkwäàd al-Ușilityyab fi Ilehtilaf al-Fuqahä' (Kairo: Mu' assasah al-Risālah, 1982), hal. 208.

${ }^{25}$ Djamil, Filsafat Hukum Islam, hal. 93-94.

${ }^{26}$ Ada sekelompok ulama yang beranggapan bahwa al-sunnah memiliki kedudukan lebih penting dari al-Qur'an (al-sunnah sebagai penentu terhadap al-Qur'an). Alasan mereka antara lain: (1) Bahwa al-Qur'an yang bersifat mignal (umum) itu memerlukan penjelasan dari al-sunnah, sehingga "kata akhir" berada pada al-sunnah, bukan pada al-Qur'an. Misalnya mengenai hukuman potong tangan bagi pencuri, al-Qur'an tidak menjelaskan ukuran benda yang dicuri itu seberapa, kemudian al-sunnah menjelaskannya yaitu sejumlah tertentu (nișäb); (2) Ada beberapa ayat al-Qur'an yang mempunyai makna ganda (mubtamal). Dalam hal ini al-sunnah memberikan alternatifnya. Hamädah, Al-Sumnab al-Nabawinyab, hal. 344-355. 
Menurut al-Sibā̄ī, sebenarnya sunnah, selain yang mutawatir, menempati urutan kedua (setelah al-Qur'an), karena ditinjau dari segi eksistensinya jelas berbeda. Tetapi jika dilihat dari segi pemahaman nas, maka pemahaman terhadap nas tidak akan benar jika tidak merujuk kepada al-sunnah. Dari sisi ini, bisa saja dikatakan bahwa al-sunnah sejajar dengan al-Qur'an. ${ }^{27}$ Yang jelas bahwa al-Qur'an dan al-sunnah adalah dua sumber yang tidak bisa dipisahkan satu sama lainnya.

\section{Pendekatan dalam Ijtihad}

Untuk memahami syari'at Islam yang dibawa Rasulullah, para ulama ushul fikih mengemukakan dua bentuk pendekatan, yaitu melalui kaidah-kaidah kebahasaan dan melalui pendekatan mäāsid al-sharỉah (tujuan syara' dalam menetapkan hukum).

Pendekatan melalui kaidah-kaidah kebahasaan adalah untuk mengetahui dalil-dalil yang 'amm dan khäsș, mutlaq dan muqayjad, migmal dan mubayyan, muhkam, mufassar, mutashäbih, nașs, zähir, näsikh, mansükh, 'amr, naby dan sebagainya. Dalam kaidah-kaidah kebahasaan ini dikemukakan cara-cara menyelesaikan dalil-dalil yang bertentangan secara zábir, sehingga seluruh dalil yang ada dalam al-Qur'an dan sunnah dapat dipahami serta diamalkan. Persoalan hukum dalam pendekatan ini terkait langsung dengan nas (al-Qur'an dan atau Sunnah).

Pendekatan maxāsid al-sharìah, penekanannya terletak pada upaya menyingkap dan menjelaskan hukum dari suatu kasus yang dihadapi melalui pertimbangan maksud-maksud syara' dalam menetapkan hukum. Teori yang digunakan untuk menyingkap dan menjelaskan hukum dalam berbagai kasus yang tidak ada nasnya secara khusus, dapat diketahui melalui metode

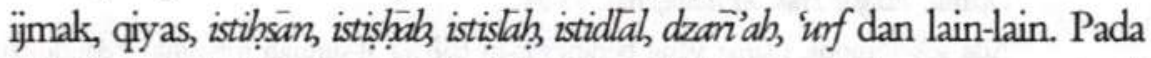
hakekatnya inti dari maxāsid al-shari'ah adalah kemaslahatan manusia di dunia dan di akhirat. ${ }^{28}$ Oleh sebab itu, berbagai metode yang digunakan

\section{${ }^{2}$ Ibid., hal. 345.}

${ }^{28}$ Muhammad Kamāl al-Din Imām, Naẓariygah al-Figh fi al-Istam (Beirut: al-Jami'ah alIskandariyyah, $1998 \mathrm{M}$ ), hal. 173. 
untuk menyingkap dan menjelaskan hukum pada setiap kasus yang tidak ada nasnya, harus senantiasa berorientasi kepada kemaslahatan umat. ${ }^{29}$

Untuk mendapatkan gambaran secara utuh tentang teori maqāsid al-shariah, diperlukan penjelasan lima pokok kemaslahatan (al-kulliyyât al-khams) dengan peringkatnya masing-masing ${ }^{30}$ (darūinjyāt, hääzyjat, dan tahsininjyat). Uraian ini bertitik tolak dari pokok kemaslahatan, yaitu : agama, jiwa, akal, keturunan dan harta. Kemudian masing-masing dari kelima pokok itu akan dilihat berdasarkan kepentingan dan kebutuhannya (skala prioritasnya).

\section{E. Hubungan antara Maqāṣid al-Sharì'ab dengan beberapa Metode Ijtihad}

Sebagaimana telah dijelaskan, pada dasarnya tujuan utama disyari'atkan hukum Islam adalah untuk memelihara kemaslahatan dan sekaligus menghindari kemafsadatan, baik di dunia maupun di akhirat. Segala macam kasus hukum, baik yang secara eksplisit diatur dalam al-Qur'an dan hadis maupun yang dihasilkan melalui ijtihad, harus bertitik tolak pada tujuan tersebut. Dalam kasus hukum yang secara eksplisit dijelaskan dalam kedua sumber utama fikih, kemaslahatan dapat ditelusuri melalui teks yang ada. Jika ternyata kemaslahatan itu dijelaskan, maka kemaslahatan itu dijadikan titik tolak penetapan hukumnya. Kemaslahatan seperti ini lazim digolongkan kepada al. masblabab al-mu'tabarab. ${ }^{31}$

Berbeda halnya jika kemaslahatan itu tidak dijelaskan secara eksplisit ke dalam kedua sumber utama. Dalam hal ini peranan mujtahid sangat penting untuk menggali dan menemukan mașlabah yang terkandung dalam penetapan hukum. Pada dasarnya hasil penelitian

\footnotetext{
${ }^{29}$ Nasrun Haroen, Ushul Fikih (Jakarta : Logos, 1996), I: xi-xii.
}

${ }^{30}$ Secara rinci mengenai uraian ini dapat dilihat dalam Muhammad Sa'id Ramaḍ̄an al-

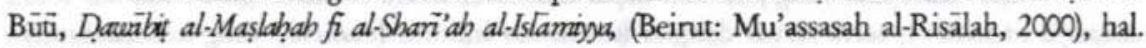
218-219.

${ }^{31}$ Kamāl al-Din Imām, Naẓariyyah al-Fiqh, hal. 172. 
itu dapat diterima, selama tidak bertentangan dengan maslaḥab yang ditetapkan dalam kedua sumber utama tersebut. Jika terjadi pertentangan, maka maslaḅab dimaksud digolongkan sebagai al-mașlạab al-mulghah. ${ }^{32}$

Pencarian para ahli ushul fikih terhadap maslahab itu diwujudkan dalam bentuk metode ijtihad. Berbagai macam istilah telah digunakan oleh mereka untuk menyebut metode penemuan hukum. Namun pada dasarnya, semua metode itu bermuara pada upaya penemuan muslahạ, dan menjadikannya sebagai alat untuk menetapkan hukum yang kasusnya tidak disebutkan secara eksplisit baik dalam al-Qur'an maupun hadis. Atas dasar asumsi ini, maka dapat dikatakan, bahwa setiap metode penetapan hukum yang dipakai oleh para ahli ushul fikih bermuara pada maquasid al-shariahab. ${ }^{33}$

Untuk melihat hubungan antara maquasid al-sharìah dengan beberapa metode penetapan hukum, dapat dilihat misalnya aspek maslahaha yang terdapat dalam qiyas, istibșän dan lainnya.

Dalam metode qiyas, ${ }^{34}$ paling tidak ada empat unsur yang harus ada, yakni așl, far', hukm al-așl, dan 'illah. ${ }^{35}$ Dari keempat unsur itu, illab-lah yang sangat penting dan sangat menentukan. Ada atau tidak adanya hukum dalam kasus baru sangat tergantung pada ada atau tidak adanya illah pada kasus tersebut. Contoh dalam bidang mu'amalah, misalnya tentang hak sbuf'ah (hak pembelian bagi seseorang yang berserikat dengan penjual dalam sebidang tanah atau tempat tinggal). Dalam hal ini persekutuan merupakan illah adanya hak sbuf'ah.

\footnotetext{
32 Ibid., hal. 173.

${ }^{3}$ Djamil, Filsafat Hukum Islam, hal. 135.
}

${ }^{3}$ Menurut 'Abd al-Wahhäb Khalläf, qiyas adalah menyamakan suatu kasus yang tidak terdapat hukumnya dalam nas dengan kasus yang hukumnya terdapat dalam nas, karena adanya persamaan illah dalam kedua kasus hukum itu. Lihat 'Abd al-Wahhäb Khalläf, Masäadir al. Tasbrì al-Islämï fi mä là nașsa fỉh (Kuwait: Där al-Qalam, 1972), hal. 19.

${ }^{35}$ Illab ialah sifat yang jelas dan dapat diketahui secara obyektif (zähij) dan ada tolok ukurnya (mndabit), serta sesuai dengan ketentuan hukum (mnäsib) yang keberadaannya menentukan adanya hukum. Lihat Wahbah al-Zuhayil, Al-Wasiț fi Ușïl al-Figh, (Damaskus: alMațba' ah al-'Ilmiyyah, 1969), hal. 415. 
Sedangkan ḥikmah-nya (tujuan atau maksudnya) adalah untuk menghindari kesulitan yang timbul disebabkan masuknya orang lain yang bukan sekutunya. Dengan demikian, persekutuan dijadikan sebagai cillah adanya hak sbuf'ah, karena diduga bahwa masuknya unsur lain dalam persekutuan itu akan terjadi kesulitan.

Berdasarkan contoh di atas dapat dipahami, bahwa dalam qiyas penemuan sillab dari hikmab sangat menentukan keberhasilan mujtahid dalam menetapkan hukum. Dari sinilah dapat dilihat betapa eratnya hubungan antara metode qiyas dengan mäasid alsharỉah. Menurut ahli ushul, hilkmab baru dapat dijadikan illah setelah diketahui dan ditelusuri maksud disyariatkan hukum itu. Dan dalam menentukan maksud dan tujuan hukum, tidak akan lepas dari memahami mașlahab dan mafsadah yang merupakan inti dari kajian maquasid al-sharìah. ${ }^{36}$ Dalam teori pencarian illab dinyatakan bahwa, salah satu syarat diterimanya șifah menjadi sillah adalah șifah tersebut harus mnäsabah, yakni sesuai dengan maslathab yang diduga sebagai tujuan disyari' atkan hukum itu. ${ }^{37}$ Dengan demikian dapat dikatakan bahwa muslahab yang menjadi tujuan utama disyariatkan hukum Islam, merupakan faktor penentu dalam menetapkan hukum melalui jalur qiyas.

Dalam metode istihsa ${ }^{38}$ (mencari yang terbaik), misalnya, juga sangat terkait dengan maquasid alsharỉah. Walaupun dalam qiyas jati illabnya dapat diketahui dengan jelas, namun pengaruhnya kurang efektif, sebaliknya pengaruh itu akan lebih kuat pada quyas khafi. Dengan menelusuri tujuan disyariatkannya suatu hukum, para mujtahid terdorong untuk beralih dari qijās jati kepada qjāas khafi.

${ }^{36}$ Fathurrahman Djamil, Opcit., hal. 138.

${ }^{37}$ Musțafa al-Shalabī, Ușì̀ al-Fiquh al-Islämï, (Beirut: Dār al-Nahḍah al-'Arabiyyah, 1986), hal. 234.

${ }^{38}$ Istihsān adalah berpalingnya mujtahid dari qiyas jali kepada qiyas khafi. Lihat Djamil, Filsafat Hukum Islam, hal. 139. 


\section{F. Macam-macam Ijtihad}

Menurut al-Shățibì (w. $790 \mathrm{H}$ ), pakar usul fikih Maliki, dalam menggali suatu hukum dari dalil syara' seorang mujtahid, di samping berijtihad secara langsung terhadap nas, juga perlu berijtihad dalam menerapkan hukum yang telah dihasilkan itu pada realitas yang ada. Oleh sebab itu, menurutnya, seorang mujtahid dalam menghadapi suatu kasus yang harus dicarikan hukumnya, perlu melakukan dua kali ijtihad yaitu:

a. Ittihä istinbātîn, yaitu berijtihad dalam memperoleh hukum dari nas yang telah ditentukan, dan

b. Ijtihäd tat $\bar{a} \bar{q}$, yaitu suatu ijtihad yang dilakukan untuk menerapkan ketentuan hukum yang telah dihasilkan dari nas tersebut.

Pada ijtihad pertama seorang mujtahid berhadapan langsung dengan nas, sedangkan pada ijtihad kedua ia berhadapan dengan kenyataan, subyek dan obyek hukum. Ada kalanya hukum yang telah dihasilkan berdasarkan ijtihad langsung pada nas itu tidak bisa diterapkan pada subyek atau obyek hukum, karena jika hukum itu diterapkan akan berdampak negatif yang lebih besar. Artinya, kemaslahatan yang ingin dicapai dari penerapan hukum yang dihasilkan melalui ijtihad istinbathi itu berhadapan dengan suatu kemudaratan atau kemafsadatan yang kualitasnya lebih besar dari kemaslahatan yang akan dicapai. Dalam kasus seperti ini, menurut al-Shāțibì, mujtahid harus mencarikan hukum lain, sehingga kemaslahatan bisa dicapai dan kemafsadatan tidak muncul. ${ }^{39}$

Dilihat dari segi pelakunya, ijtihad dapat dibedakan kepada dua macam, yaitu: ${ }^{40}$

a. Ijtihäd fanti (perorangan), yaitu ijtihad yang pelakunya hanya satu orang. Jenis ijtihad ini memungkinkan untuk dilakukan, jika

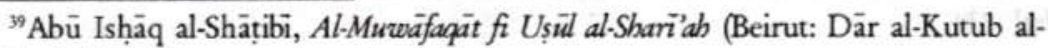
Tlmiyyah, tt), hal. 64.

${ }^{40}$ Syarifudin, Ushul Fikih, II: 272-273. 
masalah atau kasus yang menjadi objek ijtihad bersifat sederhana dan terjadi di tengah masyarakat yang sederhana, sehingga tidak memerlukan penelitian atau kajian dari berbagai disiplin ilmu. Mungkin juga si mujtahidnya menguasai berbagai disiplin yang diperlukan untuk mengkaji masalah tersebut. Umpamanya ijtihad dalam menetapkan berlakunya tayamum; apakah berlaku hanya untuk satu shalat atau lebih dari satu shalat. Yang mungkin melakukan ijtihad individual ini hanya mujtahid al-kamil yang ilmunya dapat melingkupi seluruh bidang hukum.

b. Ijtihäd jamẫ atau ijtihad kolektif yaitu ijtihad yang dilakukan oleh beberapa orang secara kolektif (bersama). Ijtihad dalam bentuk initerjadi karena masalah yang diselesaikan sangatkompleks (rumit) meliputi bidang yang luas, sehingga perlu melibatkan banyak ahli dari berbagai disiplin ilmu dan tidak mungkin dilakukan oleh seorang spesialis pada satu bidang tertentu. Umpamanya tentang bayi tabung yang tidak dapat dilakukan oleh seorang ahli hukum, tetapi setidaknya melibatkan ahli biologi dan dokter. Hasil yang dicapai dalam bentuk ijtihad kolektif ini, tidak sama dengan ijmak, karena "ulama" yang berperan dalam ijtihad ini tidak meliputi seluruh ulama yang menjadi persayaratan bagi suatu ijma.

Diakui bahwa ada beberapa masalah yang muncul sekarang ini, secara kebetulan, mirip atau bahkan sama dengan masalah-masalah yang dibahas oleh para ahli fikih terdahulu. Namun tidak sedikit masalah-masalah yang sama sekali baru, maka mujtahid pada masa sekarang ini harus menyelesaikannya dengan cara memahami secara baik masalah dimaksud kemudian membahasnya secara seksama, dengan tetap merujuk pada jiwa hukum Islam yang terkandung dalam al-Qur'an dan hadis.

Berkenaan dengan keadaan seperti di atas, maka ijtihad pada masa sekarang ini, sebagaimana dinyatakan oleh Yusuf al-Qardāw $\vec{w}$,

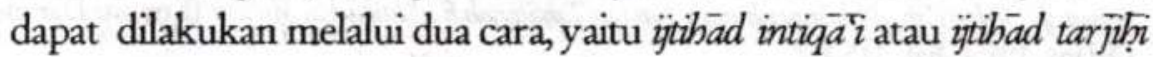




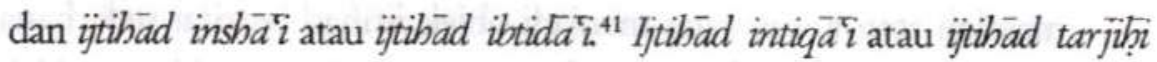
adalah ijtihad yang dilakukan seseorang atau sekelompok orang untuk memilih pendapat para ahli fikih terdahulu mengenai masalah-masalah tertentu, sebagaimana tertulis dalam berbagai kitab fikih, kemudian menyeleksi mana yang lebih kuat dalilnya dan lebih relevan dengan kondisi kita sekarang. ${ }^{42}$

Kegiatan tar $\bar{n}$ ỵang dilakukan oleh ahli tarj̆ berbeda dengan kegiatan tarjih pada kebangkitan kembali hukum Islam dan masa kemunduran hukum Islam. Tarjị pada periode ini berarti menyeleksi berbagai pendapat, dari mazhab apapun ia berasal, kemudian diambil pendapat yang rä̈l̆, yang paling kuat, berdasarkan kriteria yang telah ditetapkan.

Kemungkinan besar pendapat para ahli fikih terdahulu mengenai masalah yang sedang dipecahkan itu berbeda-beda. Dalam hal ini mujtahid mumtaqi' bertugas untuk mempertimbangkan dan menyeleksi dalil-dalil juga argumentasi-argumentasi dari setiap pendapat itu, kemudian memberikan preferensinya terhadap pendapat yang dinggap kuat dan dapat diterima.

Ada beberapa faktor yang harus diperhatikan oleh mujtahid mumtaqi. Diantara faktor-faktor itu, yang terpenting adalah perubahan sosial-budaya, kemajuan ilmu pengetahuan dan teknologi dan kesesuaian dengan tuntutan zaman. Faktor-faktor ini dapat dijadikan bahan pertimbangan ketika menyelesaikan kasus yang sedang ditetapkan hukumnya. Jadi dalam pelaksanaan ÿtihäd intiqä $i$ diperlukan analisis yang cermat terhadap masalah yang sedang di kaji. Analisis tidak terbatas pada dalil-dalil dan argumentasi yang dikemukakan para ahli fikih terdahulu, melainkan juga harus melihat relevansinya untuk masa sekarang ini.

"Pengelompokan ijtihad ini dikemukakan oleh Yusuf al-Qardāawi dalam kitabnya, al-

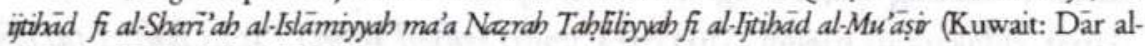
Qalam, 1985), hal. 115-117.

${ }^{42}$ Ibid, h, 125. 


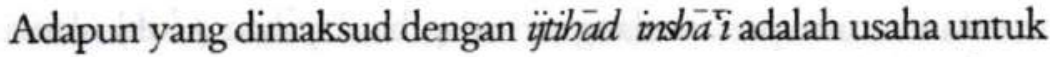
menetapkan kesimpulan hukum mengenai peristiwa-peristiwa baru yang belum diselesaikan oleh para ahli fikih terdahulu. ${ }^{43}$ Dalam ijtihad ini diperlukan pemahaman yang menyeluruh terhadap kasus-kasus baru yang akan ditetapkan hukumnya. Tanpa mengetahui secara baik apa dan bagaimana kasus yang baru itu, sulit bagi mujtahid mussic untuk dapat menetapkan hukumnya dengan baik dan benar. Jadi dalam menghadapi persoalan yang sama sekali baru, diperlukan pengetahuan mengenai masalah yang sedang dibahas, disamping pengetahuan yang menjadi persyaratan ijtihad itu sendiri.

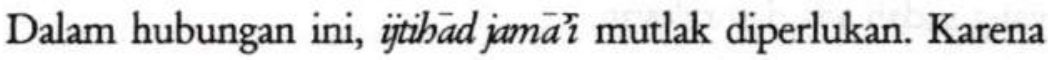
keterbatasan pengetahuan seseorang disertai semakin ketatnya disiplin ilmu pada masa sekarang ini, maka ütibäd fardi mengenai kasus yang sama sekali baru, kemungkinan besar akan membawa kepada kekeliruan. Sebagai contoh tentang pencangkokan jaringan organ tubuh manusia. Guna menetapkan hukumnya, perlu didengar lebih dahulu ahli bidang kedokteran, setelah itu dibahas dari disiplin ilmu agama, untuk kemudian diambil kesimpulan hukumnya.

Dalam ijtihad insb $\bar{a} \bar{i}$ juga diperlukan pemahaman yang baik tentang metode penetapan hukum. Ada beberapa metode yang telah dikemukakan oleh para ahli ushul fikih terdahulu. Di antara metode itu adalah qiyas, istiḅsān, istishāb, istislāh, dan sadd al-dzarì'ah, juga pengetahuan tentang tujuan disyariatkan hukum Islam (maqūsid alshari'ab), sebab pada dasarnya semua metode penetapan hukum Islam bermuara pada hal tersebut.

\section{G. Penutup}

Ijtihad masa sekarang adalah sebuah kemestian dalam rangka mencari solusi setiap masalah hukum kontemporer yang pasti berkembang seiring perkembangan masyarakat. Mujtahid masa kini diharuskan

${ }^{4}$ Ibid, hal.126. 
melakukan interpretasi ulang terhadap hasil ijtihad (fikih) ulama masa lalu yang sudah kurang relevan dengan situasi dan kondisi untuk dicarikan alternatif baru yang lebih sesuai kebutuhan, situasi dan kondisi masa kini. Jika kasus hukum itu sudah pernah dibahas oleh ulama-ulama terdahulu, maka mujtahid masa kini bisa melakukan tarjị untuk mendapatkan pendapat yang terkuat dalilnya (ütihäd intiqā $\mathbf{i}$ ). Namun jika kasus hukum itu sama sekali belum dibahas oleh ulamaulama terdahulu, mujtahid masa kini harus menggali dan menemukan jawaban hukumnya secara jamā̌s (kolektif) - jika tidak mungkin dilakukan ijtihad fardi - dengan tetap menggunakan metode usul fikih yang sudah ada dan relevan.

\section{DAFTAR PUSTAKA}

Abū Dāwud. Sunan Ab̆i Dāreed, 4 Juz. Ttp.: Dār al-Fìkr, t.t.

Abū Zahrah, Muhammad. al-Hadith wa al-Mubaddithūn Beirut: Dār al-Kitāb al-'Arabi, 1993.

Adnan Amal, Taufik. Islam dan TantanganModernitas:Studiatas Pemikiran Hukum Fazlur Rabman. Bandung: Mizan, 1994.

Amin Suma, Muhammad. Pengantar Tafsir Abkam. Jakarta : Raja Grafindo Persada, 2001.

Baso, Ahmad. "Melawan Tekanan Agama; Wacana Baru Pemikiran Fikih NU, dalam Jamal D. Rahman, etal. Wacana Baru Fikib Sosial 70 Tahum KH. Ali Yafie. Bandung: Mizan, 1997.

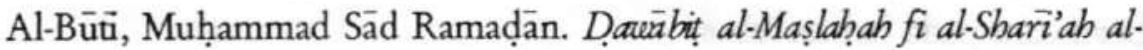
Istamizyach Beirut: Mu'assasah al-Risālah, 2000.

Djamil, Fathurrahman. Filsafat Hukum Islam. Jakarta: Logos, 1999.

Efendi, Satria, "Ijtihad Sepanjang Sejarah Hukum Islam: memposisikan K.H. Ali Yafie," dalam Jamal D. Rahman, et.al. Wacana Baru Fikih Sosial 70 Tabun KH. Ali Yafie. Bandung: Mizan, 1997.

Al-Ghazāh, Abū Ḥamid. Al-Mustasfă min Ilm al-Ușül, 2 jilid. Beirūt: Dār alKutub al-Ilmiyyah, 1983. 
Hamādah, 'Abbās Mutawalli Al-Sunnabal-Nabarwìyyahrwa Makänatuhä fial-Tasbrì'. Kairo: Dār al-Qawmiyyah, t.t.

Haroen, Nasrun. Usbul Fikih, 2 jilid. Jakarta: Logos, 1996.

Hosen, Ibrahim. "Jenis-Jenis Hukuman dalam Hukum Pidana Islam: Reinterpretasi Terhadap Pelaksanaan Aturan)," dalam Jamal D.Rahman, etal. Wacana Baru Fikib Sosial 70 Tahun KH. Ali Yafie. Bandung: Mizan, 1997.

Ibn Rushd. Bidāyabal-Mujtahid rea Nihäyah al-Muqtașid. Semarang: Thoha Putra, t.t.

Imām, Muhammad Kamāl al-Din. Naẓariyyah al-Fiqh fi al-sslām Beirut: alJami'ah al-Iskandariyyah, $1998 \mathrm{M}$.

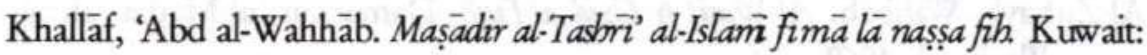
Dār al-Qalam, 1972.

Al-Khațib, ‘Ajjāj. Al-Sunnab qabla al-Tatwìn. Beirut: Dār al-Fikr, 1993.

Mahfudz, Sahal. Nuansa Fikih Sosial. Yogyakarta: LKiS, 1994.

Yahya, Mukhtar dan Fatchurrahman. Dasar-dasar Pembinaan Hukum FikibIIlami. Bandung : Al-Ma'arif, 1993.

Muslim. Șạ̦ị̣̂ Muslim. Bandung: Shirkah al-Ma'ārif li al-Ṭab' wa al-Nashr, t.t.

Nasution, Harun. "Dasar Pemikiran Pembaharuan dalam Islam," dalam M. Yunan Yusuf, et.al. (eds.), Citadan Citra Muhammadiyah.Jakarta: Pustaka Panjimas, 1985.

_. "Ijtihad Sumber Ketiga Ajaran Islam" dalam Jalaludin Rahmat (ed.), Itihad Dalam Sorotan. Bandung: Mizan, 1988.

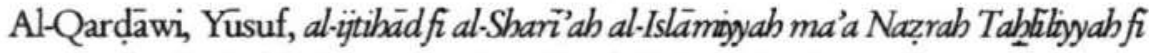
al-Ijtihäd al-Mu'assiri. Kuwait: Dār al-Qalam, 1985.

Al-Qurthubi, Sumanto. KH. M.A. Sahal Mahfudz: Era Baru Fikih Indonesia. Yogyakarta: Cermin, 1999.

Al-Khin, Mustafa Sa'id. Athar al-Ikhtiläf fi al-Qaweäi id al-Usiülyyah fi Ikhtiläf al. Fuqabả . Kairo: Mu'assasah al-Risālah, 1982.

Schacht, Joseph. AnIntroduction in Is lamic Law . London: Oxford at the Clarendon Press, 1971. 
Supani

Al-Suyūtī. Taysìr al-Ijtihād Makkah al-Mukarramah: Maktabah al-Tijäriyyah, 1982.

Al-Syalabī, Muștafá. Usül al-Figh al-Istam . Beirut: Dār al-Nahḍah al-'Arabiyyah, 1986.

Syarifuddin, Amir. Usbul Fikih, 2 Jilid. Jakarta: Logos Wacana Ilmu, 1999.

Al-Shātịīi, Abū Ishạā. Al-Murwäjaqăt fi Ușül al-Sharỉah. Beirut: Dār al-Kutub al-Ilmiyyah, t.t.

Al-Shawkān̄i, Muhammad ibn 'A 1 ibn Muhammad. Irshād al-Fuḅül. Beirut: Dār al-Fikr, t.t.

Al-Tirmidżi, Sunan At-Tìrmidż̄ 5 jilid. Beirūt: Dār al-Fikr, t.t.

Al-Zuhayin, Wahbah. Al-Wasit fi Ușül al-Figh. Damaskus: al-Mațba' ah al'Ilmiyyah, 1969. 